\title{
A Maternal Wall for Refugees? Gender and Labor Market Establishment in Sweden'
}

I Anne Grönlund²

Professor, Department of Social Work, Umeå University

I Madelene Nordlund

PhD, Sociology department, Umeå University

\begin{abstract}
Using longitudinal register data, we examined gender patterns in the long-term labor market establishment of refugees $(n \approx 11,700)$ and Swedish-born individuals $(n \approx 109,000)$. The main question was whether refugee women face greater difficulties than men and if gender differences can be attributed to care responsibilities. With multinomial logistic regression, cox regressions, and individual fixed effects models, refugees were observed at age 29-30 in 1997, then followed to age 50. Results show that both among refugees and Swedish-born, establishment was a protracted and insecure process for women. Over time, women caught up with men but in terms of stable employment, gender gaps prevailed throughout the fertile period and parenthood was negatively related to long-term establishment prospects. Future research should move beyond the focus on labor market entry to capture the mechanisms behind long term insecurities. The timing of parenthood and the importance of adult education are of particular interest.
\end{abstract}

\section{KEYWORDS}

Gender / labor market establishment / parenthood / refugees / Sweden

\section{Introduction}

ver the past decade, the worlds forcibly displaced population grew from 41.1 million in 2009 to 79.5 million by the end of 2019 (UNHCR 2019). Although the majority of people fleeing from persecution, conflict, or human rights violations seek shelter within their own or neighboring countries, an unprecedented number of refugees has reached OECD countries. As a result, the integration of refugees into labor markets and societies has become an urgent topic for policymakers as well as for scholars.

In debates on immigrant integration, refugee women are depicted as a vulnerable group. Facing a 'triple disadvantage' related to immigrant status, forced migration, and gender, they are expected to have worse employment outcomes than inborn women, other migrant women and male refugees (Liebig \& Tronstad 2018). In particular, heavy care responsibilities are pointed out as an obstacle to labor market integration. To assess - and address - these concerns, there is a need to empirically scrutinize refugees' integration processes from a gender perspective.

\footnotetext{
${ }^{1}$ You can find this text and its DOI at https://tidsskrift.dk/njwls/index.

${ }^{2}$ Corresponding author: Anne.Gronlund@umu.se.
} 
By now, a vast amount of research has demonstrated that immigrants' integration process can be complex and protracted, and more so for refugees than for other immigrants (Bevelander \& Irastorza 2014; Dumont et al. 2016). Although higher education substantially increases the prospects of employment, several studies point to the importance of country-specific human capital, such as language skills and social networks, which take time to acquire (e.g., Behtoui 2008; Tovatt 2007). In line with this reasoning, both employment rates and job skill levels tend to rise with time spent in the new country (e.g., Benton et. al. 2014; Bevelander \& Irastorza 2014; Rooth \& Ekberg 2006). Even after several years, however, substantial employment gaps remain between immigrant and native-born populations (e.g., Eriksson 2011; Dumont et al. 2016).

The fact that the establishment process is more complicated for refugees than for labor migrants makes it difficult to compare integration across countries due to the varying composition of immigrant groups (Eriksson 2011; Sebastién et al. 2010). Arguably, however, close-up studies from countries with different institutional frameworks could provide new insights about the labor market establishment of refugees and here Sweden provides an interesting case. Since 1990, two thirds of the population increase in the Nordic countries has been generated by migration and Sweden has received the largest number of immigrants both in absolute numbers and on a per capita basis. Furthermore, refugee immigration has been more important in Sweden than in other Nordic countries (Calmfors \& Sánchez Gassen 2019; Nordic council of ministers 2018; OECD 2016). Currently, the share of foreign-born residents (19\% in 2018) is larger in Sweden than in other Nordic countries (Calmfors \& Sánchez Gassen 2019, p. 10) and among the largest in European OECD countries (OECD 2016). Finally, and importantly, the Swedish institutions are particularly relevant for studying gendered patterns of refugee integration.

In recent years, the task of bringing refugee women into employment has been depicted as a particular challenge (e.g., Dumont et al. 2016; OECD 2016; Liebig \& Tronstad 2018) and, at first glance, such concerns appear to be supported by statistics. For example, Dumont et al. (2016) reported that in 2014, refugee women in Europe had a considerably lower employment rate and higher unemployment than native-born women, other female immigrants and refugee men had. At the same time, there is a conspicuous lack of studies systematically analyzing gendered patterns in labor market establishment over a longer term.

To date, these issues have been addressed mainly in the economic literature exploring the importance of culture. The basic argument is that, because immigrants bring with them norms and behaviors, immigrant women's labor supply will reflect the source country's preferences and beliefs regarding women's roles. However, while studies consistently show that women from countries with low rates female labor force participation are less often employed or in the labor force than those from more high-participation countries (e.g., Antecol 2000; Blau \& Kahn 2015; Blau et al. 2011; Neuman 2018), these studies also share many limitations. In particular, the mechanisms reproducing or weakening gender patterns from source country cultures have not been thoroughly explored.

Obviously, a range of individual and country-level factors could affect immigrant women's labor market establishment. As indicated, it is important to consider the reason for immigration - specifically by distinguishing between refugees from labor migrants and account for human capital endowments. Considering the low rates of female labor force participation in many refugee-producing countries, it can be assumed that many

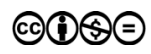


refugee women will lack the skills that are required in their new countries. European surveys indicate that refugee women have less education than men do and, at least to some extent, gender gaps in employment appear to be driven by the large share of loweducated women (Dumont et al. 2016). At the same time, a vast amount of research on labor market gender inequality points to the importance of women's care responsibilities and arguably, this factor could be particularly pertinent for refugees. Here, it can be noted that although women constitute about $45 \%$ of the immigrants arriving to European OECD countries for reasons of international protection, they are less likely than men to come as asylum applicants and more likely to arrive as family migrants, either accompanying their refugee husband or joining him later (Liebig \& Tronstad 2018). To our knowledge, however, the importance of care responsibilities has not been thoroughly explored in quantitative studies on immigrants' labor market integration.

To further our understanding of gendered patterns, we take a long-term view of refugees' labor market establishment in Sweden. The Swedish policies designed to help immigrants integrate into the labor market are described by the OECD as highly developed (OECD 2016) and Sweden scores high on the EU Migration Immigration Policy Index (Mipex 2015). However, when studying gender patterns, also other institutions must be considered. Previously, a large body of comparative research has demonstrated that both gendered patterns of employment in general and the specific importance of parenthood varies between countries with different welfare state and family policy arrangements (e.g., Budig et al. 2012; Korpi et al. 2013). As discussed below however, the Swedish institutions could provide both obstacles and opportunities to refugee women.

The dual-earner model of Swedish social policy (e.g., Korpi 2000), based on an encompassing welfare state and extensive family policies, has incorporated women and mothers into the labor market at internationally high rates. At the same time, gender differences persist in terms of wage and career prospects (Boye et al. 2017; Grönlund et al. 2017; Magnusson \& Nermo 2017) and the gendered division of family responsibilities remains an important source of such inequalities (e.g., Boye et. al. 2017). A further complication is that both skill requirements and entry wages are high in the Swedish labor market (OECD 2016). Arguably, individuals from countries where traditional gender norms have limited women's access to education and paid work could face particular challenges in this context; at the same time, the institutionalized support for women's labor market participation could provide new possibilities for development, economic independence, and gender equality.

In Sweden, the gaps in employment rates between the foreign-born population and native-born population are large by international comparison, particularly for women. Clearly, these gaps reflect the high employment rates of the native-born women and in absolute terms, employment rates of immigrant women in Sweden are above the OECD average (OECD 2016). ${ }^{1}$ Nevertheless, the situation of refugee women in Sweden has been addressed by international observers (e.g., Dumont et al. 2016; Liebig \& Tronstad 2018; OECD 2016) as well as in Swedish debates. Recently, Swedish governmental commissions have argued that immigrant women have particularly high thresholds to the labor market, pointing to mothers' care responsibilities as a serious impediment for women from non-OECD countries (SOU 2012, 2016).

Swedish research analyzing refugee labor market establishment from a gender perspective is limited and inconclusive regarding the long-term patterns and mechanisms. A number of studies suggest that, initially, refugee women are less established than 
men but that over time, gender gaps narrow (Andersson Joona et al. 2017; Andersson Joona 2020; Bevelander \& Irastorza 2014; Hernes et al. 2020; Liebig \& Tronstad 2018; Ruist 2018; Åslund et al. 2017). However, gender is not the prime focus in any of these studies and the mechanisms behind these patterns have not been thoroughly explored, either for initial gaps or for later convergence tendencies. Here, the shortand long-term implications of gendered care responsibilities is of particular interest. These issues are also of obvious policy relevance. In recent years, debates and reforms in many countries - including Sweden - have emphasized the importance of early labor market establishment. An underlying concern is that initial establishment problems will lead to a permanent exclusion from the labor market. Previous labor market research has documented that youth unemployment has negative long-term repercussions (e.g., Schmillen \& Umkehrer 2017) and similar scarring effects may appear in the process of immigrants' integration. Thus, early establishment could be crucial to refugee women's long-term economic independence as well as their general inclusion in society, for which working life provides a central arena. Because many refugee women arrive in a family context, the responsibilities for small children could provide an obstacle to early establishment. At the same time, considering the extensive family policies - which provide generous parental leaves as well as low-cost full-time childcare for all children from age one - it is not obvious that motherhood would hinder labor market engagement in the longer perspective.

Against this background, we set out to explore if refugee women face greater employment difficulties than refugee men; if differences are explained by women's larger care responsibilities and, finally, if parenthood implies an initial slowdown or a permanent exclusion from the labor market. We use longitudinal register data to follow the labor market establishment of male and female refugees in Sweden between the ages of 30 and 50. To separate between short- and long-term effects of parenthood and the potential scarring of initial establishment problems, we use a two-stage approach. First, we examine the establishment patterns of refugee men and women and how they are related to gendered care responsibilities. Second, we study the issue of scarring by analyzing how men and women lacking establishment at age 30 fare in the long term and whether parenthood increase the risk of permanent exclusion. To put the gender patterns among refugees in perspective, corresponding analyses are performed for the Swedish-born population.

\section{Aim and research questions}

The aim of the study is to explore gender differences in labor market establishment among refugees and relatives of refugees in Sweden. A central issue is whether care responsibilities provide a short- and/or long-term obstacle for women's employment. To contextualize our findings, corresponding analyses are conducted for the native-born population.

The following questions are addressed:

RQ 1. Are refugee women less well established than refugee men at age 30?

RQ 2. What are the long-term employment prospects of individuals who were unestablished at age 30 ? Do the trajectories differ between men and women? 
RQ 3. Can gender differences in labor market establishment at age 30 be ascribed to women's care responsibilities, as measured by parenthood? Does parenthood imply a permanent exclusion from the labor market?

RQ 4. To what extent do the patterns found in RQ1-RQ3, appear also in the Swedishborn population?

\section{Data and method}

The study is based on cross-sectional and longitudinal analyses of register data from Statistics Sweden. The data comes from the linked databases of STATIV and LISA. STATIV is a longitudinal database developed to provide a basis for studying the integration of immigrants in different areas of society. In international perspective, the register is considered to be unique (EU 2016). LISA, the Longitudinal integrated database for health insurance and labor market studies, comprises the total population of individuals aged 16 and above. Both databases are updated annually and we use data starting from 1997, which was the first year of STATIV, through 2016, which was the last year available at the time of our analysis. Thus, we can follow individuals over a period of 20 years. Together, these databases provide a range of variables capturing the employment and unemployment, income and welfare state transfers (e.g., parental leave compensation), education and family structure.

Two separate populations are studied in the analysis. The first population comprises refugees aged 29-30 in 1997 ( $\mathrm{n}=11,727$ ). This population consists of immigrants who had been granted a residence permit based on the status of refugee or subsidiary protection (registered as 'humanitarian reasons' and 'in need of protection'). The dataset (referred to below as refugees) also include individuals who were granted a residence permit as 'relatives of refugee'. We focused on refugees (rather than the immigrant population at large) because they face particularly strong obstacles to entering the labor market and are the main concern in debates on integration policies. Also, with a narrow focus, there are less compositional factors confounding the analysis of gender differences. In order to understand better our findings, we also conduct corresponding analyses on the Swedish-born population. This dataset comprises inborn Swedes aged 30 in 1997 ( $\mathrm{n}=109,000)$. The choice of age group was motivated by our ambition to follow individuals over a long period and throughout the years of childrearing and labor market establishment. To focus on individuals who had finished their education and were eligible for the labor market, we set the age to 30. According to Statistics Sweden, the average age for labor market establishment was particularly high in 1997, around 30 years for women and 27 years for men (SCB 2002). Arguably, many low-educated individuals may be established before that age, however a large share of young people have precarious employment. By using the overall establishment age, we avoid including a group that is still in full-time education. Due to limitations in the education variable, these are more clearly excluded by using age and considering that Swedish women are more likely than men are to attend university, women's labor market establishment would be underestimated with a low age limit.

The dependent variable in the analysis is labor market establishment. This is a dichotomized indicator distinguishing between individuals who were established and those who were not established. To be classified as established individuals had to be 
employed. In the LISA database, individuals are counted as employed if they have (a) an employer in November or (b) an active firm, as defined by the Swedish Tax Agency. This official employment variable was constructed to capture a more stable employment corresponding to the ILO definition of employment. To further strengthen the indicator, we added the following criteria: an annual income from work corresponding to at least half a median work income, zero days in unemployment, and zero days of participation in active labor market policy programs (ALMP) during the year. Thus, we capture individuals who are strongly established in the labor market, excluding subsidized employment and more erratic work episodes. The focus on gender patterns and care responsibilities also required a careful consideration of parental leaves. To qualify for full parental benefits in Sweden (that is 480 days compensated at $80 \%$ of the income level), the individual needs to be employed for 240 consecutive days before the birth of the child. However, individual without current or previous employment receive parental benefits at a flatrate level and such benefits are also available to immigrants arriving with children. To address this issue, individuals on parental leave are counted as established if they have an employer or an active company and otherwise meet the criteria for establishment. If they lack such a connection to the labor market, they are categorized as unestablished. Accounting for these aspects (subsidized employment and parental leave) is important for assessing gender differences in short- and long-term establishment.

This indicator was developed in order to overcome weaknesses in previously used measures.

Failing to include parental leave payments can distort findings on gender patterns in establishment, for example, if women with stable jobs are mistakenly regarded as unestablished. Relying on the official definition of employment is not enough, particularly since the classification changed (in 2004) so that individuals on parental leave are counted as employed, regardless if they had an employer (in November). To our knowledge, these problems have not been addressed in previous research and therefore, women's establishment may be both over- and underestimated. More generally, previous studies may have overestimated the establishment of weakly attached groups by measuring establishment either with the official employment variable (see above) or as the first year with (any) income from employment (e.g., Andersson Joona et al. 2015; Liljeberg 2016). Such measures are problematic because they can include employment in/income from active labor market programs (ALMP)). Since these are often directed towards individuals with establishment problems, results may be biased and we do not know whether such programs lead to 'real' (unsubsidized) jobs. Some researchers have addressed these problems by including income criteria (Åslund et Al. 2017; Ruist 2018) or excluding individuals with any days in unemployment during the year (Strandh $\&$ Nordlund 2008). Here, we not only use both these criteria but also specifically exclude individuals in active labor market programs from the category of established. In sum then, our indicator distinguishes those who were strongly established (during a certain year) from those who were unestablished. Individuals classified as unestablished were not employed, had zero income from work or self-employment, zero days on unemployment benefit, and zero days in ALMP studies/employment.

To get a broader picture, we performed complementary analyses using a more generous definition of establishment. Here, individuals who had an annual income (from wages/self-employment) corresponding to at least half a median work income were categorized as established even if they were not employed in November. Also,

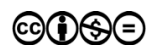


individuals who were employed but fell below the income threshold were included. Basically, then, this additional category, referred to below as weakly established, comprises all individuals who had any employment during the year- ranging from those who had been working for a substantial part of the year but left employment at the end of the year to those with very erratic job episodes and those who with only subsidized jobs in ALMP-activities.

Individuals on permanent sick leave have been excluded from the analysis. Individuals in education are included but this factor is controlled for in the analysis. ${ }^{2}$

Below, we first conduct a cross-sectional analysis capturing the likelihood of labor market establishment in 1997, when the individuals were 30 years old. For this, we use multinomial logistic regressions with three categories: established, weakly established, and unestablished (reference category). As explained above, we focus on the likelihood of being established as compared to being unestablished but will also briefly discuss the likelihood of being weakly established.

Separate analyses are carried out for men and women, and the focus of interest lies in the importance of women's care responsibilities. Therefore, we include three dummy variables capturing parenthood: having children aged $0-3$ (yes/no), having children aged 4-6 (yes/no), and having children aged 7 or more (yes/no). Here, we also control for marital status (married or cohabiting versus the reference category single), though it should be noted that cohabiting couples can only be identified if they have children. In the refugee data, we also distinguish relatives of refugees from individuals classified as refugees. Human capital is captured with level of education, which comprises primary/unknown education (reference category), secondary education, and tertiary education. Unfortunately, the register data does not allow us to separate between education acquired in the country of origin and that acquired after arriving in Sweden. This is unfortunate considering that the latter may be relevant for immigrants' employment prospects (Arendt et al. 2020). To get more correct measures of both establishment and level of education, we also control for current participation in education. Because participation is measured in the autumn term, this variable allows us to separate individuals who are taking part in an ongoing education from those who got their degrees in the spring and are now available for the labor market. In the regressions for refugees, we also include a continuous measure of years since immigration, capturing the time the individual has spent in Sweden after receiving his/her residence permit (i.e., excluding the asylum-seeking period during which refugees were generally not allowed to work). ${ }^{3}$ This indicator can be regarded as a rough proxy of country-specific human capital, such as language skills and cultural knowledge, and is a crucial factor for labor market establishment (Rooth \& Åslund 2007). To account for the possibility that prospects of employment can diminish after a certain number of years, we also use a curvilinear variable for time in Sweden. Finally, we control for region of origin. The indicator comprises five categories, namely Europe (reference category), the Middle East plus North Africa, Sub-Saharan Africa, Latin America, and Asia. The last three categories correspond to the World Bank classification of regions (World Bank 2017). However, in contrast to the World Bank, we use separate categories for Europe, Asia and Oceania (and place Malta in Europe rather than North Africa). Descriptive statistics are presented in the Result section.

In the next part, we study labor market establishment in the longer term. Here, we explore the establishment prospect of individuals classified as unestablished in 1997. 
To get an overview, we first report the annual percentage of labor market establishment 1998-2016 in four groups: refugee women, refugee men, Swedish-born women, and Swedish-born men. Next, we conduct a longitudinal analysis where we follow the individuals over 20 years, until they reach the age of 49-50. The analysis aims to investigate whether the individuals classified as unestablished in 1997 enter the labor market at any point between 1998 and 2016. To acquire this information, it is suitable to use a cox regression that measures both if unestablished individuals become established and when such a transition takes place. Furthermore, cox regressions enable us to determine how a transition from one state to another correlates with different independent variables. Finally, another advantage of the cox regression is that also those individuals who do not transfer to labor market establishment during the period under study can be included in the analysis and treated as censored cases. The specification of the cox regression is:

$$
h(t)=h_{0}(t) \times e\left(b_{1} x_{1}+b_{2} x_{2}+\cdots\right)
$$

The rate of events is estimated by the hazard function $h(t)$ (if individuals move from the category of unestablished to being established). We use a large number of independent variables $(x)$ are in the regression in order to investigate how these may influence the hazard of transition. The independent variables $(x)$ influence the dependent variable (the hazard). The $(b)$ is the regression coefficient (the logarithm of the hazard ratios of event occurrence) and the base of the natural logarithm is expressed as $(e)$. Finally, $h_{0}(t)$ is the baseline hazard function, which indicates that the value on $x$ is zero. In other words, it captures the odds ratio of transits to establishment before accounting for the independent variables. In the tables, the results of the cox regressions are displayed by B-coefficients, which is the logarithm of the hazard ratios of event occurrence, and their standard errors (SE). We use standard errors instead of the significance levels to avoid confusion. Because the data comprises the total population (i.e., all individuals aged 29-30 in 1997 who were living in Sweden during the observation period), significance levels are not immediately interpretable because the observed values are the true values for the population. Nevertheless, standard errors can provide a descriptive picture of the strength of the relationships. The general assumption in a cox regression is that the 'risk' that an event occurs is proportional over time (unrelated to time). That is, the likelihood of a transition to establishment is assumed to be equal for each year. (For a detailed statistical description, see Singer \& Willett, 2003).

We complement the results from the cox regressions by applying a number of fixed effects models on our data (Allison 2009). The purpose is two-fold. First, in contrast to cox regressions, fixed effect models allow us to include events that occur during the observation period. Considering our focus on care responsibilities, we have included a variable capturing each event of having a child after 1997 . Here, each year without a new child takes the value 0 while each year with a new child takes the value 1 . Second, fixed effect models control for time-constant unobserved individual characteristics that may differ systematically between groups and bias the relationships under study (for example, selection into parenthood or return migration). Clearly, time-varying individual characteristics not controlled for in our models could still influence the results. Finally, we underline that the results should not be made subject to causal interpretation.

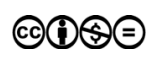




\section{Results}

In the first step of the analysis, we examine the situation of our cohort of refugees in 1997, when they were 29-30 years old. As mentioned, this population also includes those who were classfied as relatives of refugees.

The descriptive statistics in Table 1a shows a clear gender gap in refugees labor market establishment. First, we note that a large majority $(68 \%)$ of the female refugees were unestablished, meaning that they had no employment contract or income from employment, unemployment benefits or ALMP activities. Among male refugees, 51\% were unestablished. Second, only $5 \%$ of the women were established in the labor market, as compared to $12 \%$ of the men. If weakly established individuals - that is, those with more erractic job episodes and/or in subsidized ALMP employment - are included

Table Ia Characteristics of refugee population aged 29-30, year 1997. Valid percentages

\begin{tabular}{|c|c|c|c|c|c|c|}
\hline & \multicolumn{2}{|c|}{ Total sample } & \multicolumn{2}{|c|}{ Unestablished } & \multicolumn{2}{|c|}{ Established } \\
\hline & Women & Men & Women & Men & Women & Men \\
\hline Established & 4.8 & 12.0 & & & & \\
\hline Weakly established & 27.0 & 37.2 & & & & \\
\hline Unestablished & 68.2 & 50.9 & & & & \\
\hline \multicolumn{7}{|l|}{ Family indicators } \\
\hline Married & 70.6 & 49.0 & 75.1 & 49.5 & 48.9 & 42.0 \\
\hline Have children & 77.8 & 39.2 & 83.7 & 39.5 & 28.2 & 22.7 \\
\hline Children 0-3 yrs & 49.8 & 31.9 & 58.0 & 31.9 & 6.4 & 15.4 \\
\hline Children 4-6 yrs & 38.8 & 16.6 & 43.1 & 17.1 & 7.9 & 12.2 \\
\hline Children $7<$ yrs & 41.3 & 10.7 & 43.1 & 11.1 & 19.5 & 9.5 \\
\hline Relative (ref: Refugee) & 25.7 & 6.2 & 28.4 & 6.6 & 16.5 & 6.4 \\
\hline
\end{tabular}

\begin{tabular}{lcccccc}
\hline Highest level of education & \multicolumn{1}{l}{} \\
\hline Primary/Unknown education & 39.9 & 34.2 & 46.5 & 39.7 & 24.1 & 27.9 \\
\hline Secondary education & 38.4 & 41.3 & 35.1 & 39.0 & 36.8 & 41.5 \\
\hline Tertiary education & 21.6 & 24.2 & 18.3 & 21.4 & 39.1 & 30.6 \\
\hline In education & 26.3 & 24.7 & 26.2 & 27.3 & 21.1 & 15.8 \\
\hline Years in Sweden (mean) & 5.2 & 5.8 & 4.7 & 5.8 & 6.8 & 6.6 \\
\hline Region of origin & & & & & & \\
\hline Europe & 38.6 & 30.5 & 37.9 & 28.5 & 34.8 & 33.9 \\
\hline Middle East \& North Africa & 41.6 & 50.6 & 44.7 & 55.2 & 32.4 & 37.8 \\
\hline Latin America & 6.3 & 5.1 & 4.3 & 2.7 & 11.2 & 8.1 \\
\hline Sub-Saharan Africa & 6.9 & 7.6 & 5.1 & 6.8 & 13.6 & 9.7 \\
\hline Asia & 6.6 & 6.3 & 6.8 & 5.9 & 8.0 & 10.6 \\
\hline N & 5598 & 6129 & 3818 & 3117 & 266 & 735 \\
\hline
\end{tabular}


the figures rise and gender gaps are smaller. Thus, at age 30, refugee women were considerably less likely than their male counterparts to be in the labor market, particularly in more stable 'real' jobs.

The statistics also point to distinct gender patterns in family roles and responsibilities. A large majority of the female refugees, but only a minority of the male refugees, had children. Further, the fact that women were four times more likely than men to have children aged 7 or older suggests that they often were parents before migrating to Sweden. Gender patterns are found also in marriage rates and, on immigration, about one-fourth of the women were classified as relatives of refugees rather than refugees. In contrast, gender differences were small for human capital indicators and region of origin.

Table $1 \mathrm{~b}$ displays the characteristics of Swedish-born individuals of the same cohort. Only $26 \%$ of the women were established, compared to $47 \%$ of the men. However, a majority of women had a weak attachment to the labor market, as defined above. In contrast to the refugees, then, only a small minority of the Swedish-born population were unestablished at age 30 and although gender gaps appeared in this group, too, they were smaller than for refugees. In comparison to refugees, both marital rates and the share of parents were smaller in the Swedish-born population. Women were more likely than men to be parents at age 30, but the gender gap was small compared to that among refugees. In particular, Swedish-born women were considerably less likely than refugee women to have older children (aged < 7). Finally, the educational level was considerably higher in the Swedish-born population and here, women had more education than men. Thus, there was a huge educational gap between refugee women and Swedish-born

Table Ib Characteristics of Swedish-born population aged 30, year 1997. Valid percentages

\begin{tabular}{|c|c|c|c|c|c|c|}
\hline & \multicolumn{2}{|c|}{ Total sample } & \multicolumn{2}{|c|}{ Unestablished } & \multicolumn{2}{|c|}{ Established } \\
\hline & Women & Men & Women & Men & Women & Men \\
\hline Established & 25.8 & 46.5 & & & & \\
\hline Weakly established & 62.7 & 45.9 & & & & \\
\hline Unestablished & 11.5 & 7.5 & & & & \\
\hline \multicolumn{7}{|l|}{ Family indicators } \\
\hline Married & 35.8 & 24.4 & 32.5 & 11.6 & 20.2 & 16.4 \\
\hline Have children & 64.9 & 40.0 & 71.1 & 20.8 & 13.2 & 16.3 \\
\hline Children 0-3 yrs & 42.5 & 31.5 & 49.0 & 14.0 & 5.0 & 10.7 \\
\hline Children 4-6 yrs & 34.0 & 17.8 & 34.3 & 9.0 & 7.4 & 8.3 \\
\hline Children $7<$ yrs & 26.2 & 16.7 & 39.2 & 27.7 & 11.0 & 12.8 \\
\hline
\end{tabular}

Human capital

\begin{tabular}{lcccccc}
\hline Highest level of education & & & & & \\
\hline Primary/unknown education & 10.5 & 12.5 & 24.3 & 27.5 & 5.6 & 9.7 \\
\hline Secondary education & 58.2 & 57.5 & 57.9 & 53.7 & 50.8 & 54.4 \\
\hline Tertiary education & 31.3 & 30.0 & 17.9 & 18.8 & 43.6 & 35.8 \\
\hline In education & 15.4 & 10.1 & 28.0 & 25.2 & 10.1 & 6.2 \\
\hline $\mathrm{N}$ & 53,143 & 55,857 & 6097 & 4213 & 13,726 & 25,995 \\
\hline
\end{tabular}


women, where the former group was about four times as likely to have only primary/ unknown education.

In sum, two characteristics distinguished the female refugees both from male refugees and from Swedish-born women (and men). First, they were much less likely to be established in the labor market. Second, many women started their integration process as wives and mothers. ${ }^{4}$ Refugee women also differ from Swedish-born women, who tend to enter parenthood at a higher age and be better educated when they do. Nevertheless, gender gaps in establishment are found also in the Swedish-born population.

The tables further suggest that family responsibilites are differently related to labor market establishment for men and women. Among refugees (Table 1a), we find that mothers - particularly those with young children - are over-represented in the unestablished group, as are married women and women who immigrated to Sweden as relatives. Among male refugees, the share of married individuals and parents was no higher in the unestablished group than in the total population. Table $1 \mathrm{~b}$ shows that in the Swedish-born population, too, parents are underrepresented in the established group. Mothers, particularly those with small or school-age children, are also over-represented in the unestablished group, while the share of fathers is lower in the unestablished group than in the population at large. Among Swedish-born, the share of married individuals is lower both in the unestablished group and the established groups, compared to the total population. ${ }^{5}$ For Swedish-born and refugees alike, individuals with lower education were over-represented in the unestablished group and under-represented among the established. Among refugees, these composition of these groups also varied regarding average time in Sweden, immigrant status and country of origin. Notably, the share of individuals from the Middle East/North Africa was considerably lower in the established group than in the total population.

Below, we explore how these characteristics correlate with labor market establishment for men and women, both among refugees and in the Swedish-born population.

\section{Labor market establishment in 1997}

In Tables $2 \mathrm{a}$ and $2 \mathrm{~b}$, we examine the predictors of labor market establishment at the base year of 1997. The results are based on multinominal regressions and we focus on the likelihood of being established, as compared to being unestablished. However, coefficients for the likelihood of weak establishment are also displayed and will be referred to for comparison.

Table $2 \mathrm{a}$ shows the results for male and female refugees, respectively. The most prominent finding is that, for female refugees, parenthood clearly reduced the likelihood of being established at age 30. The negative correlation decreases with the children's age but remains significant for all categories. The odds ratio of being established on the labor market for refugee women with children aged 0 to 3 was 0.041 , as compared to women who had no children. Meanwhile, the odds ratio of being established was 0.33 for refugee women with school-age children in comparison to non-mothers. Married refugee women were somewhat more likely to be established than those who were single (i.e., unmarried, divorced, or widowed). For weak establishment, patterns for refugee women are similar but considerably less pronounced. School-age children, marital status, and refugee/relative status were uncorrelated with weak establishment. 
Table 2a Labor market establishment 1997 among refugees, male and female, aged 29-30. Multinomial regressions. (Reference category $=$ Unestablished)

\begin{tabular}{|c|c|c|c|c|}
\hline & \multicolumn{2}{|c|}{ Female } & \multicolumn{2}{|c|}{ Male } \\
\hline & $\begin{array}{l}\text { Established } \\
\text { Exp(B) }\end{array}$ & $\begin{array}{l}\text { Weakly } \\
\text { Exp(B) }\end{array}$ & $\begin{array}{l}\text { Established } \\
\text { Exp(B) }\end{array}$ & $\begin{array}{l}\text { Weakly } \\
\text { Exp(B) }\end{array}$ \\
\hline Married (ref: Not married) & I.504***** & 1.088 & $1.332 * *$ & 1.062 \\
\hline \multicolumn{5}{|l|}{ Children (ref: No child) } \\
\hline Children $0-3$ years & .041 粎 & .448 ***** & $.342 * * * *$ & 1.298**** \\
\hline Children 4-6 years & $.123 * * * *$ & $.679 * * * *$ & .780 & .899 \\
\hline Children $7<$ years & $.330 * * * *$ & .920 & .841 & $.860 *$ **** \\
\hline Relative (ref: Refugee) & .762 & .854 & .966 & .833 \\
\hline \multicolumn{5}{|l|}{$\begin{array}{l}\text { Highest level of education } \\
\text { (ref: Primary/Unknown) }\end{array}$} \\
\hline Secondary education & 1.733**⿻丷木 & $2.23 \mid * * * *$ & 1.476***** & 1.447 ****** \\
\hline Tertiary education & $3.293 * * * *$ & $2.700 * * * *$ & $2.57 \mid$ **** & 1.782**** \\
\hline In education 1997 & .335 ***** & .690 ****** & $.380 * * * *$ & 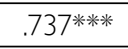 \\
\hline Years in Sweden & 1.380***** & $1.28 \mid * * * *$ & 1.248**** & 1.176 ***** \\
\hline \multicolumn{5}{|l|}{ Region of origin (ref: Europe) } \\
\hline Middle East and North Africa & $.275 * * * * 1$ & $.483 * * * * *$ & $.287 * * * *$ & $.582 * * * * 1$ \\
\hline Latin America & 1.125 & 1.181 & 1.200 & 1.696***** \\
\hline Sub-Saharan Africa & .820 & 1.093 & 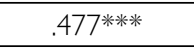 & $.667 * * * *$ \\
\hline Asia & .658 & $.738 *$ & .900 & .7||$*$ \\
\hline Pseudo R2 (per cent, Nagelkerke) & 28.9 & & 13.8 & \\
\hline $\mathrm{N}$ & 5598 & & 6129 & \\
\hline
\end{tabular}

Table 2b Labor market establishment 1997 among Swedish-born individuals, male and female, aged 30. Multinomial regressions. (Reference category $=$ Unestablished)

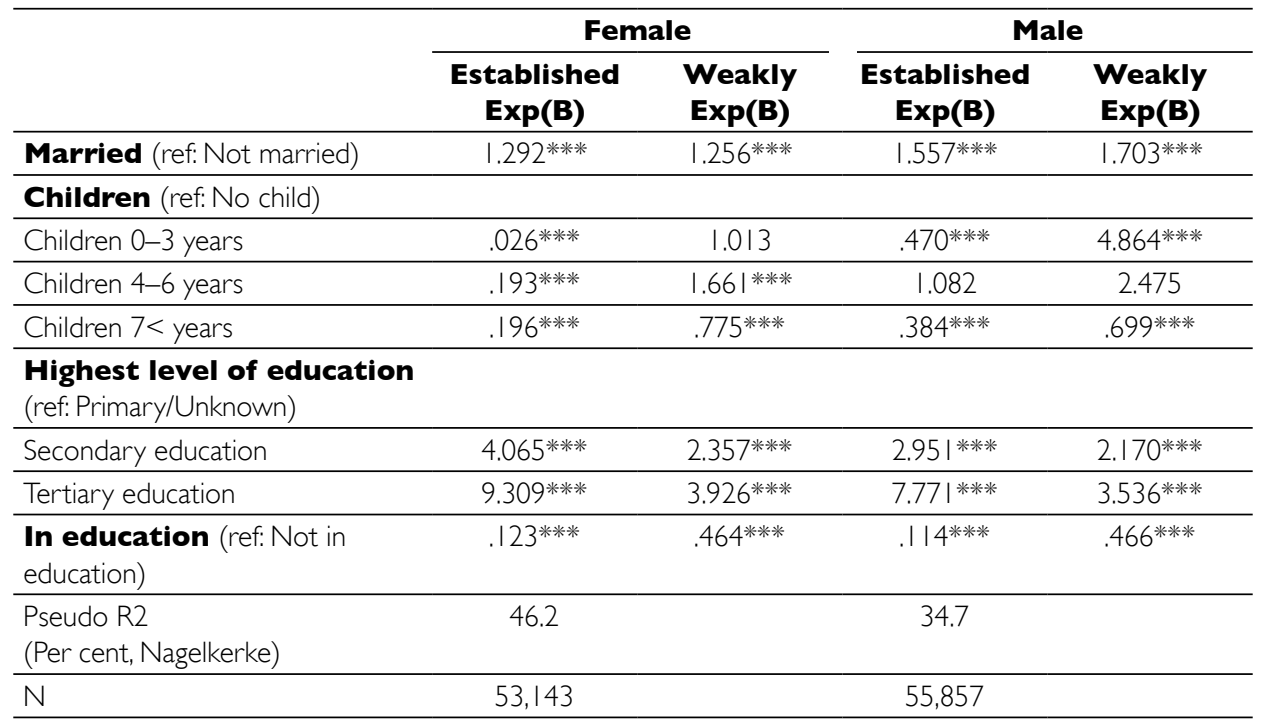


Among male refugees, the pattern is less clear. As shown, refugee men with small children ( $0-3$ years) were less likely to be established than men who were not fathers. The coefficients for older children are generally not statistically significant for refugee men, though having school-age children was negatively correlated with weak establishment. For marital status, results point in the same direction for men as for women. Also, the human capital variables formal education and time in Sweden were positively correlated with establishment in both groups. For example, for female refugees with tertiary education, the odds ratio of being established was 3.3 compared to those with only primary education. However, even controlling for family status and human capital, the likelihood of establishment was lower for refugees from the Middle East/North Africa region, as compared to refugees from Europe. Among male refugees, this was true also for individuals from Sub-Saharan Africa.

Table $2 \mathrm{~b}$ display the results for Swedish-born women and men. For women, parenthood clearly mattered for labor market establishment at age 30. For example, for Swedish-born women with small children, the odds ratio of labor market establishement was 0.026 compared to those with no children. Swedish-born fathers were also less likely to be established than non-fathers. For weak establishment, negative correlations were found for school-age children, whereas for younger children correlations were positive. These patterns were found for both men and women.

In sum, we find that care responsibilities for young children are related to lower rates of labor market establishment among women, both among refugees and in the Swedishborn population. Importantly, this finding is not a mere reflection of parental leave uptakes, since our dependent variable was constructed to classify mothers on parental leave as established if they have an employer. Also, it does not reflect previous or current participation in education. However, for all groups, the relationship between parenthood and establishment appears to be complex and to get a full picture, also weak establishment must be considered. Taking this broader view, we find that in 1997, refugee women with care responsibilites were more often outside the labor market than childless women. This disadvantage was found both for stable employment and more insecure employment (weak establishment). For men - both refugee men and Swedish-born men - having small children was not a barrier for entering the labor market but may be related to the strength of labor market attachment. To some extent, the latter applies also to Swedish-born women. In essence, pre-school children did not exclude Swedish women from the labor market altogether but was related to the strength of their labor market attachment. For individuals who had school-age children at age 30, the patterns differed across groups. Among Swedish-born men and women, and among refugee men, population, this group stood out with a lower likelihood of both stronger and weaker establishment. For refugee women, however, older children posed less of a barrier to establishment, at least to weak establishment.

Finally, pseudo R2-values are higher for women than for men, and higher for Swedish-born individuals than for refugees. Taken together, the variables considered here explain $46 \%$ of the variation in establishment for Swedish women, compared to $35 \%$ for Swedish men, $29 \%$ for refugee women, and 14\% for refugee men.

\section{Long-term labor market establishment}

Next, we will examine the long-term prospects for labor market establishment for men and women in both populations. 
Figur 1 shows the rate of labor market establishment 1998-2016 for individuals who were categorized as unestablished at age 30. Separate curves are displayed for female refugees, male refugees, Swedish-born women and Swedish-born men. As shown, a substantial share of the individuals who were unestablished at age 30 gained access to the labor market over the twenty-year period. However, the curves differ between the groups. ${ }^{6}$ In particular, gender differences are prominent. Men's establishment rates intially rise sharply and continue to rise for about ten years. In 2009, men's establishment rates fall (possibly in relation to the economic crisis at the time), then recover. Establishment rates for refugees mirrow those of Swedish-born men but are slightly lower up until the last few years when only refugees establishment continues to rise. As for men, establishment patterns for refugee women follow those of Swedishborn women but at a slighly lower level. Compared to men, women's curves are flatter but establishment rates continue to rise over the whole period. As a result, a substantial gender gap appears for most of the fertile years (32-42). At its widest amounts to 10 and 11 percentage points among refugees and Swedish-born individuals, later it narrows, down to 6 percentage points among refugees and 2 percentage points in the Swedish-born population.

Figure I Yearly rates of labor market establishment 1998-2016 among individuals who were unestablished in 1997.

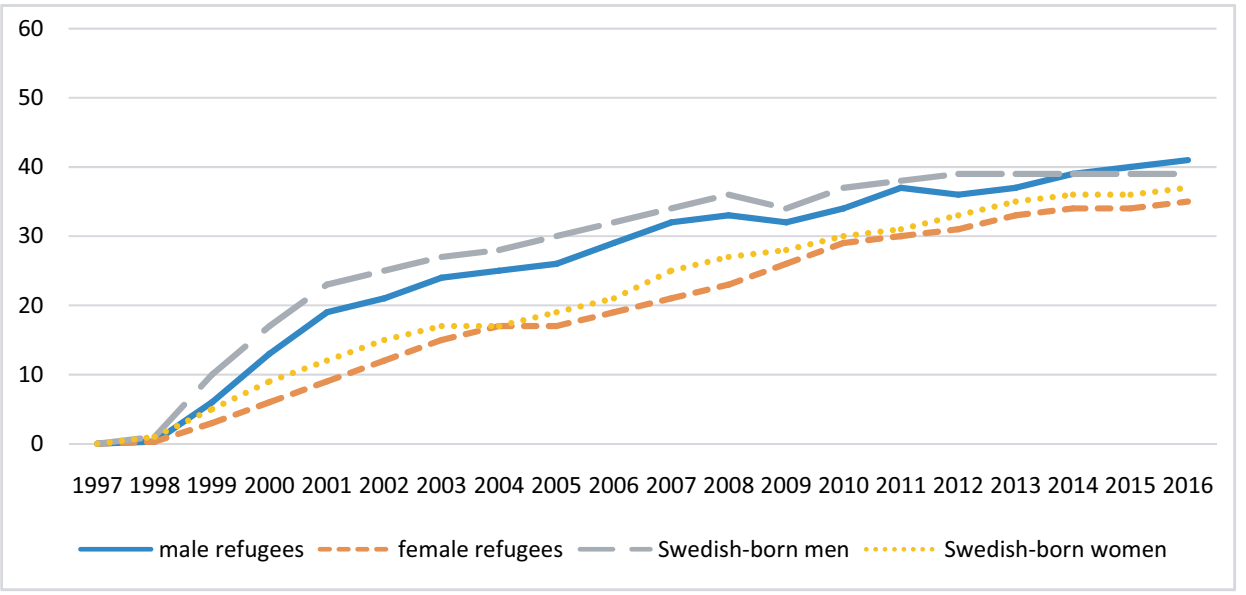

For weak labor market establishment (Figure A-1, Appendix), the curves look very different. Here, the establishment rates for men rise steeply for two years, then fall at a decreasing pace for most of the period. For women, the steep intial increase continues longer and although the levels then decrease they remain higher than for men. Refugee men catch up with Swedish men after a few years. Intially, the establishment rate of refugee women is lower but after four years surpasses that of men and after 10 years, refugee women catch up with Swedish women. All in all, these pattern suggest that over the long term, too gender patterns are more prominent than differences between the refugee and the Swedish-born population. However, regarding weak establishment refugee women fall behind Swedish women throughout the most fertile period. 
Arguably, these patterns suggest that Swedish-born men who are unestablished at age 30 (a comparatively small group) may be negatively selected regarding characteristics relevant to productivity. For the other groups, lack of establishment at this age more often reflects a transitional state that can be related to care responsibilities or recent immigration. As demonstrated in previous research, a lack of countryspecific human capital - notably, language skills - will slow down the labor market establishment of immigrants and from that perspective, the extended labor market establishment for refugees displayed in Figure 1 may not be surprising. Still, the different curves for men and women are noteworthy. The figure shows that for refugee women, the process of labor market establishment continued for the whole period under study, up until the age of 50. Among the refugees, a much smaller share of the women were established at age 30, but over the years they caught up with men. Arguably, these patterns indicate that refugee women are not permanently locked out of the labor market.

This image of women cathcing up is further illustrated if we widen the focus from the initally unestablished group to consider the total share established individuals in 2016. In Table A3, Appendix we find that, at age 50, about $80 \%$ of both male and female refugees were established on the labor market. For the Swedish-born population, the corresponding figure was about $93 \%$. However, if weak establishment is excluded gender gaps appear also in 2016, particularly among refugees.

To better understand individual trajectories, we performed longitudinal analysis. Here, Cox regressions were used to estimate how individual characteristics at age $30-$ notably, care responsibilities - affected the likelihood of getting established at some point between 1998 and 2016.

The results for refugees are displayed in Tables $3 \mathrm{a}$ and $3 \mathrm{~b}$. In Table $3 \mathrm{a}$, model 1 , we find that in general, female refugees who were mothers at age 30 were no less likely to move from the unestablished to the established category than those who were childless, with the exception of mothers with children in the 4-6 age group for which the long-term probability of establishment was slightly lower than for non-mothers. Marital status was not correlated with long-term establishment prospects and the negative coefficient for immigrating as a relative turned non-significant after controlling for human capital and country of origin in model 2.

As shown in Table $3 \mathrm{~b}$, parenthood at age 30 did not correlate with the long-term establishment prospects of refugee men. For both refugee men and women, individuals with secondary and, particulary, tertiary education were more likely to get established also in the long run. Finally, refugees from the Middle East (both women and men) and North Africa, Asia, and Sub-Saharan Africa (men) had lower chances of getting established in the Swedish labor market over the 19-year period.

The results from Cox regressions for the Swedish-born population are presented in Tables 3c and 3d. Table 3c, model 1, shows that having children at age 30, particularly small children or school-age children, was negatively correlated with Swedish-born women's long-term establishment. For men, none of the coefficients for parenthood are significant in Table 3d, model 1 . For both men and women, long-term establishment prospects were markedly better for individuals with tertiary education, compared to those with only primary education, as seen in Tables $3 \mathrm{c}-3 \mathrm{~d}$, model 2 . For women, education also explains the negative correlation between school-age children and longterm establishment. These findings support previous studies which show that the age of 
family formations differs between educational groups in Sweden (Kramarzb 2019) and that early parenthood can have negative implications for women's labor market establishment (cf. Engdahl et al. 2018). To some extent, however, differences between women and men could also reflect a gendered selection into parenthood and employment (cf. Boschini \& Sundström 2018).

To control for selection effects as well as for the potential impact of having a new child during the period of observation, we applied four separate fixed-effect models. The results, presented in Table 4, are comparable to the cox-regressions reported above but the fixed-effects models also control for unobserved individual characteristics that are stable over time (so that they do not confound the within-person changes under study). ${ }^{7}$ Here, we note that the gender difference in the likelihood for an individual who was unestablished age 30 to become established later is similar in the refugee population and the Swedish-born population. Having a child after 1997 is negatively correlated to establishment prospects in both populations and among

Table 3a Cox regression estimates on the hazard of refugee women transferring from unestablishment 1997 to establishment, 1998-2016'. B-coefficients and standard errors

\begin{tabular}{|c|c|c|c|c|}
\hline & \multicolumn{2}{|c|}{ Model I } & \multicolumn{2}{|c|}{ Model 2} \\
\hline & $\mathbf{B}$ & SE & B & SE \\
\hline \multicolumn{5}{|l|}{ Children in 1997 (ref: No children) } \\
\hline Children $0-3$ years & -.090 & .051 & -.070 & .054 \\
\hline Children 4-6 years & $-.113 *$ & .050 & $-.112 *$ & .051 \\
\hline Children $7<$ years & -.013 & .051 & .017 & .054 \\
\hline Married 1997 (ref: Not married) & .046 & .060 & .069 & .063 \\
\hline Relative (ref: Refugee) & $-.21 \mid * * * *$ & .057 & $-.07 \mid$ & .059 \\
\hline \multicolumn{5}{|l|}{$\begin{array}{l}\text { Level of education } \mathbf{1 9 9 7} \\
\text { (ref: Primary/Unknown) }\end{array}$} \\
\hline Secondary education & & & $.145 *$ & .058 \\
\hline Tertiary education & & & .265 ***** & .069 \\
\hline In education 1997 & & & .178 ****** & .055 \\
\hline Years in Sweden 1997 & & & .023 & .035 \\
\hline Years in Sweden $1997^{2}$ & & & -.001 & .003 \\
\hline \multicolumn{5}{|l|}{ Region of origin (ref: Europe) } \\
\hline Middle East \& North Africa & & & $-.55 \mid$ ***** & .059 \\
\hline Latin America & & & -.180 & .118 \\
\hline Sub-Saharan Africa & & & -.226 & .122 \\
\hline Asia & & & -.135 & .103 \\
\hline Chi2 & 20.041 & & & \\
\hline -2 LL 0-model & 22735.142 & & & \\
\hline$-2 \mathrm{LL}$ & 22714.779 & & 22479.364 & \\
\hline $\mathrm{N}$ & 3176 & & & \\
\hline
\end{tabular}

'Fifty-five percent of the unestablished transferred from being unestablished to established at some point between 1998 and 2016. 
Table 3b Cox regression estimates on the hazard of refugee men transferring from unestablishment 1997 to establishment, 1998-2016'. B-coefficients and standard errors

\begin{tabular}{|c|c|c|c|c|}
\hline & \multicolumn{2}{|c|}{ Model I } & \multicolumn{2}{|c|}{ Model 2} \\
\hline & B & SE & B & SE \\
\hline \multicolumn{5}{|l|}{ Children 1997 (ref: No children) } \\
\hline Children $0-3$ years & .063 & .064 & .020 & .065 \\
\hline Children 4-6 years & .005 & .072 & -.115 & .073 \\
\hline Children $7<$ years & .104 & .082 & .035 & .083 \\
\hline Married I997 (ref: Not married) & .069 & .063 & .102 & .065 \\
\hline Relative (ref: Refugee) & .062 & .096 & .051 & .098 \\
\hline \multicolumn{5}{|c|}{ Level of education 1997 (ref: Primary/Unknown) } \\
\hline Secondary education & & & $.125 *$ & .062 \\
\hline Tertiary education & & & $\left..24\right|^{* * * * *}$ & .072 \\
\hline In education 1997 & & & $.17 \mid * * *$ & .058 \\
\hline Years in Sweden 1997 & & & $.008 *$ & .024 \\
\hline Years in Sweden $1997^{2}$ & & & -.002 & .002 \\
\hline \multicolumn{5}{|l|}{ Region of origin (ref: Europe) } \\
\hline Middle East \& North Africa & & & -.492 ***** & .062 \\
\hline Latin America & & & -.149 & .150 \\
\hline Sub-Saharan Africa & & & $-.420 * *$ & .134 \\
\hline Asia & & & $-.315 *$ & .121 \\
\hline Chi2 & 8.927 & & & \\
\hline -2 LL 0-model & 19761.584 & & & \\
\hline$-2 \mathrm{LL}$ & 19752.783 & & 19587.949 & \\
\hline $\mathrm{N}$ & 2316 & & & \\
\hline
\end{tabular}

'Sixty-six percent of the unestablished transferred from being unestablished to established at some point between 1998 and 2016.

Table 3c Cox regressions estimates on the hazard of Swedish born women transferring from unestablishment 1997 to establishment, 1998-2016!. B-coefficients and Standard Errors are displayed

\begin{tabular}{|c|c|c|c|c|}
\hline & \multicolumn{2}{|c|}{ Model I } & \multicolumn{2}{|c|}{ Model 2} \\
\hline & B & SE & B & SE \\
\hline \multicolumn{5}{|l|}{ Children 1997 (ref: No children) } \\
\hline Children $0-3$ years & -.187 ****** & .039 & $-.142 * * * *$ & .041 \\
\hline Children 4-6 years & -.067 & .039 & -.035 & .040 \\
\hline Children $7<$ years & $-.125 * *$ & .040 & -.045 & .041 \\
\hline Married I997 (ref: Not married) & $.123 * * *$ & .040 & $.082 *$ & .040 \\
\hline \multicolumn{5}{|l|}{$\begin{array}{l}\text { Level of education } \mathbf{1 9 9 7} \\
\text { (ref: Primary/unknown) }\end{array}$} \\
\hline Secondary education & & & .088 & .051 \\
\hline Tertiary education & & & $.428 * * * *$ & .061 \\
\hline In education 1997 & & & $.137 * * * *$ & .040 \\
\hline Chi2 & 34.487 & & & \\
\hline-2 LL 0-model & 42402.661 & & & \\
\hline$-2 \mathrm{LL}$ & 42368.131 & & 42289.268 & \\
\hline $\mathrm{N}$ & 5389 & & & \\
\hline
\end{tabular}

$155(n=2984)$ percent of the unestablished transferred from being unestablished to established at some point between 1998 and 2016. 
Table 3d Cox regressions estimates on the hazard of Swedish born men transferring from unestablishment 1997 to establishment, 1998-2016'. B-coefficients and Standard Errors are displayed

\begin{tabular}{|c|c|c|c|c|}
\hline & \multicolumn{2}{|c|}{ Model I } & \multicolumn{2}{|c|}{ Model 2} \\
\hline & B & SE & B & SE \\
\hline \multicolumn{5}{|l|}{ Children I997 (ref: No children) } \\
\hline Children $0-3$ years & .082 & .062 & .108 & .062 \\
\hline Children $4-6$ years & .014 & .075 & .050 & .075 \\
\hline Children $7<$ years & -.041 & .051 & -.018 & .051 \\
\hline Married 1997 (ref: Not married) & .039 & .069 & .033 & .069 \\
\hline \multicolumn{5}{|c|}{ Level of education 1997 (ref: Primary/unknown) } \\
\hline Secondary education & & & .081 & .057 \\
\hline Tertiary education & & & .436 ***** & .070 \\
\hline In education 1997 & & & $.140 * *$ & .049 \\
\hline Chi2 & 4.469 & & & \\
\hline$-2 \mathrm{LL}$ 0-model & 28939.530 & & & \\
\hline$-2 \mathrm{LL}$ & 28935.142 & & 28861.052 & \\
\hline $\mathrm{N}$ & 3527 & & & \\
\hline
\end{tabular}

'6I percent of the unestablished transferred from being unestablished to establishment at some point between 1998 and 2016.

Table 4 The likelihood of labor market establishment 1998-2016 among women and men who were unestablished in 1997

\begin{tabular}{|c|c|c|c|c|c|c|c|c|}
\hline \multirow[b]{3}{*}{ Intercept } & \multicolumn{4}{|c|}{ Women } & \multicolumn{4}{|c|}{ Men } \\
\hline & \multicolumn{2}{|c|}{ Refugee } & \multicolumn{2}{|c|}{ Swedish } & \multicolumn{2}{|c|}{ Refugee } & \multicolumn{2}{|c|}{ Swedish } \\
\hline & $21.954^{* * * * *}$ & .169 & $21.356 * * * * *$ & .122 & 29,989****** & .225 & $26.174 * * * *$ & .161 \\
\hline New children 98-I6 & $-|8.4|$ ***⿻丷木大 & .814 & $-13.196 * * * *$ & .720 & $-6,\left.60\right|^{* * * * *}$ & .798 & 8.829米米 & .871 \\
\hline $\mathrm{R} 2$ & 0.008 & & 0.003 & & 0.002 & & 0.001 & \\
\hline
\end{tabular}

Fixed effects models through univariate general linear models. B-coefficients are to be interpreted as percentages. The variable child takes the value $=I$ in the year of birth and the value $=0$ for years in which no child was born.

both males and females. It is clear that having a child (after age 30) has a strong negative effect on women's establishment prospects and a significant positive effect for Swedish-born men.

\section{Conclusions}

The challenges of integrating refugee women in the labor force are increasingly highlighted, both at the Nordic and the European level (e.g., European Commission 2018; Nordic council of ministers 2018). At the same time, there is a conspicuous lack of research analyzing refugee integration processes from a gender perspective. 
To address these concerns, we analyzed the long-term labor market establishment of male and female refugees in Sweden, using longitudinal register data. We set out to explore if establishment at age 30 reflected gendered care responsibilities, if initial establishment problems had long-term scarring effects and if women's care responsibilities implied a risk of permanent exclusion. Corresponding analyses were conducted for the Swedish-born population.

The results point to distinct and strikingly similar gender patterns in the refugee population and among Swedish-born individuals of the same cohort. Compared to men, women's labor market establishment appears as a protracted and insecure process. At age 30, women - particularly refugee women - were more often unestablished and if they were working, they were considerably less likely than men to have a stable foothold in the labor market. In the long run, women appeared to catch up with men in terms of establishment; however, in terms of stable employment, this process took a remarkably long time. In fact, marked gender gaps prevailed throughout the fertile period.

Our analysis suggests that women's establishment trajectories are sensitive to life stage factors, specifically care responsibilities. For women, both refugee and Swedishborn, parenthood at age 30 was negatively related to establishment, both initially and over the long term, and having (additional) children after age 30 further lowered the chances of obtaining a firm foothold in the labor market. For Swedish-born men, no scarring effect of parenthood could be discerned and, having (additional) children after age 30 was positively related to long-term establishment. In the Swedish context, with strong institutions supporting female and maternal employment, these findings are notable. At the same time, the results do not support the notion that parenthood implies a permanent exclusion of refugee women from the Swedish labor market. Rather, their integration appears to continue into high ages and in this process, education stood out as a positive factor. Higher education was important to initial establishment but also seemed to counteract the long-term scarring effects of initial establishment problems.

Women's care responsibilities are regularly invoked to explain gendered labor market outcomes, yet, to our knowledge, our study is the first to explore the importance of parenthood for the long-term establishment of refugees. Methodologically, we contribute with a measure of establishment that separates regular employment from ALMPinterventions and is sensitive to the construction of parental leave schemes. Arguably, accounting for these factors could be crucial when assessing the employment trajectories of women and men, particularly in Nordic welfare states.

The main thrust of our analysis was to study long-term establishment by following distinct groups throughout and beyond the years of child-rearing. This approach not only has its strengths but also certain limitations. The analysis focused on one cohort and presumably, results could be affected by the composition of the refugee population. At the time, a relatively large share were refugees from the Balkan wars, which appear to have been comparatively successful. Among Swedish-born, the unestablished group is rather small and despite our attempts to control for unobservable individual characteristics, selectivity due to, for example, economic cycles cannot be ruled out with one cohort. Also, despite the high-quality registers there were data limitations regarding human capital variables. Finally, our analysis has focused on within-group patterns without directly comparing effects across groups and it should be underlined that the analysis does not allow for causal interpretations. 
In future, our findings could be corroborated with other cohorts and methods. More generally, further attention should be paid both to the mechanisms producing, and to those counteracting, gendered employment trajectories. Based on our study, we propose three main tasks for research. First, the timing of parenthood in the establishment process should be more closely examined. The fact that, for many refugee women, the initial integration period coincides with the most intensive years of childcare appears to complicate establishment. However, the timing of parenthood could affect the establishment prospects also for Swedish-born women (cf. Engdahl et al. 2018). Arguably, early parenthood can also reduce the protection offered by family policies. In Sweden, substantial and flexible parental leaves allow parents to care for children without jeopardizing their jobs but, in many ways, the usage of these rights presumes a secure employment contract. Second, the role of adult education for mitigating exclusion is an important issue with obvious policy relevance (cf. Hernes et al. 2020). Finally, the re-structuring of labor markets implies new uncertainties that are particularly pertinent to immigrants (e.g., Åberg 2015). Considering these factors, we propose that research on integation moves beyond the focus on labor market entry to study also long-term insecurities in labor market attachment. Here, both labor market segregation by gender and ethnicity and work-family tensions should be considered.

\section{Acknowledgement}

For financial support, the authors gratefully acknowledge the Swedish Research Council for Health, Working Life and Welfare, FORTE, grant number 2017-00226.

\section{References}

Allison, P. D. (2009). Fixed Effects Regression Models. Series Quantitative Applications in Social Sciences, Sage.

Antecol, H. (2000). An examination of cross-country differences in the gender gap in labor force participation rates, Labor Economics, 7(4): 409-426.

Arendt, J. N., Pohl Nielsen, C., Jacobsen, V. (2020). The importance of origin and destination country skills for labor market attachment of immigrants from Pakistan, Iran and Turkey, Nordic Journal of Migration Research 6(2): 72-80. doi: http://dx.doi.org/10.1515/njmr2016-0015.

Andersson Joona, P., Lanninger, AW., Sundström, M., (2015). Etableringsreformens första år - en första utvärdering [The first year of the establishment reform]. Rapport 2015: 3 . Institutionen för social forskning, Stockholms universitet.

Andersson Joona, P., Wennemo Lanninger, A., Sundström, M. (2017). Etableringsreformens effekter på integrationen av nyanlända [The effects of the establishment reform on the integration of the newly arrived], Arbetsmarknad \& Arbetsliv 23(1).

Andersson Joona, P. (2020). Flykting- och anhöringinvandrares väg till arbete. [The path to work for refugees and relatives of refugees] Forskningsrapport. Stockholm: SNS.

Benton, M., Fratzke, S., Sumption, M. (2014). Moving up or standing still? Access to middle-skilled work for newly arrived migrants in the EU. MPI and ILO, Washington and Geneva: Institute and International Labour Office.

Behtoui, A. (2008). Informal recruitment methods and disadvantages of immigrants in the Swedish labor market, Journal of Ethnic \& Migration Studies 34(3): 411-30. doi: http:// dx.doi.org/10.1080/13691830701880251. 
Bevelander, P., Irastorza, N. (2014). Catching Up: The Labor Market Outcomes of New Immigrants in Sweden. Washington, DC and Geneva: Migration Policy Institute and International Labour Office.

Blau, F. D., Kahn L. M., Papps, K. L. (2011). Gender, source country characteristics and labor market assimilation among immigrants, Review of Economics and Statistics 93(1): 43-58. doi: http://dx.doi.org/10.1162/REST a 00064.

Blau, F. D., Kahn, L. M. (2015). Substitution between individual and source country characteristics: Social capital, culture, and US labor market outcomes among immigrant women, Journal of Human Capital 9(4): 439-482. doi: http://dx.doi.org/10.1086/683542.

Boschini, A., Sundström, M. (2018). Det ojämlika faderskapet. [The unequal fatherhood] Ekonomisk debatt, 4(46).

Boye, K., Halldén, K., Magnusson, C. (2017). Stagnation only on the surface? The implications of skill and family responsibilities for the gender wage gap in Sweden, 1974-2010, British Journal of Sociology 68(24): 595-619. doi: http://dx.doi.org/10.1111/1468-4446. 12252.

Damm, A., Åslund, O. (2017). Foreword, in Damm, A. \& Åslund, O. (eds.) Labour Market Integation in the Nordic Countries. Nordic Economic Policy Review TemaNord 2017: 520. Nordc council of Ministers.

Budig, M. J., Misra, J., Boeckmann, I. (2012). The motherhood penalty in cross-national perspective: The importance of work-family policies and cultural attitudes, Social Politics: International Studies in Gender, State \& Society 19: 163-193. doi: http://dx.doi. org/10.1093/sp/jxs006.

Calmfors, L., Sánchez Gassen, N. (eds.) (2019). Integrating Immigrants into the Nordic Labour Markets, Copenhagen: Nordic Council of Ministers. doi: http://dx.doi.org/10.6027/ Nord2019-024.

Dumont, J-C., Liebig, T., Peschner, J., Tanay, F., Xenogiani, T. (2016). How are refugees faring on the labor market in Europe? A first evaluation based on the 2014 EU Labor Force Survey ad hoc module, EU DG Employment Working paper 1: 2016. doi: http://dx.doi. org $/ 10.2767 / 350756$.

EU (2016). Labor Market Integration of Refugees: Strategies and Good Practices. Study for the EMPL Committe, Directorate General for Internal policies. Policy Department A: Economic and scientific policy. 14 / 33 IP/A/EMPL/2016-08.

European Commission (2018). Integration of migrant women. A key challenge with limited policy resources. European website on integration, Available at: https://ec.europa.eu/migrant-integration/feature/integration-of-migrant-women [Accessed June 14, 2021].

Engdahl, M., Godard, M., Nordström Skans, O. (2018). Inträdet på arbetsmarknaden och familjebildningen. [Early labor market prospects and family formation] Uppsala: IFAU. Rapport 2018: 28.

Eriksson, S. (2011). Utrikes födda på den svenska arbetsmarknaden. [The foreign-born on the Swedish labor market] Appendix 4 till Långtidsutredningen LU 2011.

Grönlund, A., Halldén, K., Magnusson, C. (2017). A Scandinavian success story? Women's labour market outcomes in Denmark, Finland, Norway and Sweden, Acta Sociologica 60(2): 97-119. doi: http://dx.doi.org/10.1177/0001699316660595.

Hernes, V., Arendt, J., Andersson Joona, P., Tronstad, K. (2020). Rapid or long-term employment? A Scandinavian comparative study of refugee integration policies and employment outcomes, Journal of European Public Policy. doi: http://dx.doi.org/10.1080/13501763.2020.1824011.

Korpi, W. (2000). Faces of inequality. Gender, class and patterns of inequalities in different types of welfare states, Social Politics 7(2): 127-191. doi: http://dx.doi.org/10.1093/sp/7.2.127.

Korpi, W., Ferrarini, T., Englund, S. (2013). Women's opportunities under different family policy constellations: Gender, class and inequality tradeoffs in western countries re-examined, Social Politics 20: 1-40. doi: http://dx.doi.org/10.1093/sp/jxs028. 
Kramarzb, F., Nordström Skans, O., Rosenkvist, O. (2019). Humankapital och fertilitet samband inom och mellan familjer. [Skills, education and fertility - and the confounding impact of family background] Uppsala: IFAU Rapport 2019: 11.

Liebig, T., Tronstad, R. (2018). Triple Disadvantage? A first overview of the integration of refugge women. OECD Social, Employment and Migration Working Papers 216. OECD Publishing, Paris. doi: http://dx.doi.org/10.1787/3f3a9612-en.

Liljeberg, L., (2016). Effekter för olika deltagargrupper inom arbetsmarknadsutbildningen [The impact of the labour market education for different participant groups], IFAU rapport 2016: 20.

Magnusson, C., Nermo, M. (2017). Gender, parenthood and wage differences: The importance of time- consuming job characteristics, Social Indicators Research 131(2): 797-816. doi: http://dx.doi.org/10.1007/s11205-016-1271-z.

Mipex (2015). Migrant integration policy index 2015, Available at: http://www.mipex.eu/ sweden, [Accessed July 3, 2018].

Neuman, E. (2018). Source country culture and labor market assimilation of immigrant women in Sweden: evidence from longitudinal data, Review of Economics of the Household 16: 585-627. doi: http://dx.doi.org/10.1007/s11150-018-9420-6.

Nordic council of ministers (2018). Nyanlända kvinnors etablering. En komparativ studie av nyanlända kvinnors etablering på arbetsmarknaden I Norden och de etableringspolitiska insatserna. [The establishment of newly arrived women. A comparative study of the establishment of newly arrived women on Nordic labour markets and the establishment policy interventions] Tema Nord 2018: 520, Copenhagen: Nordic council of ministers.

OECD (2016). Skills and Labor Market Integration of Immigrants and their Children in Sweden, OECD, Paris. doi: http://dx.doi.org/10.1787/9789264257382-en.

Rooth, D-O., Ekberg, J. (2006). Occupational mobility for immigrants in Sweden, International Migration 44: 2: 57-77. doi: http://dx.doi.org/10.1111/j.1468-2435.2006.00364.x.

Rooth, D-O., Åslund, O. (2007). Får utlandsfödda betalt för sin utbildning och sina kunskaper i svenska? [Do foreign-born get paid for their education and their knowledge of Swedish?] Ekonomisk Debatt, 3.

Ruist, J. (2018). Tid för integration - en ESO-rapport om flyktingars bakgrund och arbetsmarknadsetablering. [Time for integration - an ESO-report on refugees' background and labor market establishment] Rapport till Expertgruppen för studier i offentlig ekonomi 2018: 1. Stockholm: Regeringskansliet, Finansdepartementet.

Sébastien, J., Causa, O., Jiménez, M., Wanne, I. (2010). Migration and labour market outcomes in OECD countries, OECD Journal: Economic Studies 2010(1): 1-34.

Singer J. D., Willett, J. B. (2003). Applied Longitudinal Data Analysis. Modelling Change and Event Occurrence. Oxford University Press, Oxford.

SCB (2002). Arbetskraftsprognos 2002. Utvecklingen till år 2020. [Labor market prognosis 20002. Developments to 2020] Information om utbildning och arbetsmarknad 1: 2002, Swedish Statistical Bureau.

Schmillen, A., Umkehrer, M. (2017). The scars of youth: Effects of early-career unemployment on future unemployment experience, International Labour Review 156(3-4): 465-494. doi: http://dx.doi.org/10.1111/ilr.12079.

SOU (2012). Med rätt att delta. Nyanlända kvinnor och anhöriginvandrare på arbetsmarknaden. [With right to participate. Newly arrived women and relatives of refugees on the labour market] SOU 2012: 69.

SOU (2016). Begränsningar i föräldrapenningen för föräldrar som kommer till Sverige med barn. [Limitations of parental leave compensation for parents that arrive in Sweden with children] SOU 2016: 73.

Strandh, M., Nordlund, M. (2008). Active labour market policy and unemployment scarring: A ten-year Swedish panel study, Journal of Social Policy 37(3). 
Tovatt, C. (2007). Det sociala kapitalets betydelse för att få en plats på arbetsmarknaden. [The importance of social capital for labor market participation] In Dahlstedt, M et. Al. (eds) Utbildning, Arbete, Medborgarskap: Strategier för social inkludering $i$ den mangetniska staden, Boréa, Umeå.

UNHCR (2020). Global trends. Forced displacement in 2019, Available at: https://www. unhcr.org/statistics/unhcrstats/5ee200e37/unhcr-global-trends-2019.h [Accessed June 14, 2021].

Åberg, R. (2015). Svensk arbetsmarknad mot polarisering efter millennieskiftet. [Swedish labor market towards polarization in the new millennial], Arbetsmarknad \& Arbetsliv 21(4): 8-25.

Åslund, O., Forslund, A., Liljeberg, L. (2017). Labour market entry of non-labour migrants Swedish evidence, In Damm, A. \& Åslund, O. (eds.) Labour Market Integration in the Nordic Countries. Nordic Economic Policy Review, TemaNord 2017: 520, Nordic council of Ministers.

World Bank (2021). How does the World Bank classify countries? Available at: https://datahelpdesk.worldbank.org/knowledgebase/articles/378834-how-does-the-world-bankclassify-countries [Accessed June 14, 2021].

\section{Notes}

${ }^{1}$ In fact, all Nordic countries display larger immigrant-native employment disparities than the OECDcountries on average. This is largely a reflection of high (female) labor force participation and should not be confused with absolute outcomes (Damm \& Åslund 2017; OECD 2016).

${ }^{2}$ Only individuals for which data is provided for all 19 years are included in the analysis. Over the period, a few per cent of our population disappear from LISA, both immigrants and Swedish-born individuals. A possible reason may be outmigration and with our approach we avoid the risk that our results are biased by selective outmigration (for similar reasoning, see, e.g., Neuman 2018). To some extent, however, the lack of information on outmigration may limit our and other researchers' possibilities to pinpoint the establishment prospects for immigrants.

${ }^{3}$ In this dataset, $30 \%$ of the women and $10 \%$ of the men hade children even before entering Sweden.

${ }^{4}$ It should be noted that cohabiting is a widespread practice in Sweden and as mentioned, cohabiting individuals without children are classified as single in the registers.

${ }^{5}$ Please note that the figure shows the annual share of established invidiuals in each group and not individual trajectories.

${ }^{6}$ The time-invariant predictors used in the cox regressions are not included in the fixed effect models. This is because the individual cases function as their own controls because they are measured at several (19) time-points. 


\section{Appendix}

Table Al Percentage of women and men in the refugee and Swedish-born populations that were established on the labor market at age 30 and 50

\begin{tabular}{|c|c|c|c|c|c|c|c|c|}
\hline & \multicolumn{2}{|c|}{$\begin{array}{c}\text { Refugees age } \\
29-30\end{array}$} & \multicolumn{2}{|c|}{$\begin{array}{l}\text { Refugees } \\
\text { age } 50\end{array}$} & \multicolumn{2}{|c|}{$\begin{array}{c}\text { Swedish-born } \\
\text { age } 30\end{array}$} & \multicolumn{2}{|c|}{$\begin{array}{c}\text { Swedish-born } \\
\text { age } 50\end{array}$} \\
\hline & Women & Men & Women & Men & Women & Men & Women & Men \\
\hline Established & 4.8 & 12.0 & 42.8 & 55.9 & 25.8 & 46.5 & 67.1 & 77.9 \\
\hline $\begin{array}{l}\text { Including weakly } \\
\text { established }\end{array}$ & 32.5 & 50.2 & 80.6 & 80.2 & 88.7 & 92.7 & 92.7 & 93.3 \\
\hline
\end{tabular}

Figure AI Yearly rates of weak labor market establishment 1998-2016 among individuals who were unestablished in 1997.

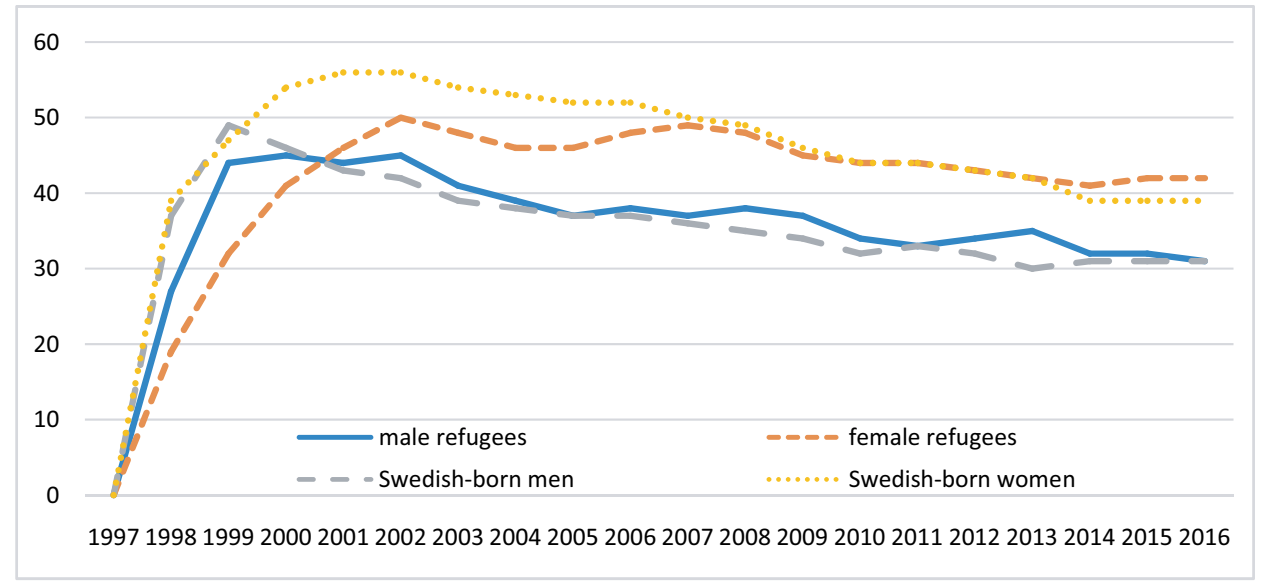

